\title{
Late Sovereign Diplomacy
}

\author{
Adler-Nissen, Rebecca
}

Published in:

Hague Journal of Diplomacy

DOI:

$10.1163 / 187119109 \times 440870$

Publication date:

2009

Document version

Early version, also known as pre-print

Citation for published version (APA):

Adler-Nissen, R. (2009). Late Sovereign Diplomacy. Hague Journal of Diplomacy, 4(2), 121-141.

https://doi.org/10.1163/187119109X440870 


\title{
Late Sovereign Diplomacy*
}

\author{
Rebecca Adler-Nissen \\ Department of Political Science, University of Copenhagen, Øster Farimagsgade 5 \\ DK-1353 Copenhagen K, Denmark \\ ran@ifs.ku.dk
}

Received: 21 November 2008; revised: 4 April 2009; accepted: 6 April 2009

\begin{abstract}
Summary
Most scholars are inclined to assume that the diplomatic practices of the European Union's member states remain fundamentally unchanged. The EU's Council of Ministers is accordingly seen as a setting where sovereign states speak with one another. Yet if state interaction in the EU is only viewed from this perspective, a number of important qualitative changes will remain underexposed. This article argues that leading political forces in the European states have come to view their nations as anchored so deeply within the supranational institutions of the EU that their diplomats merge the promotion of national interests with those of the Union. In this late sovereign phase of diplomacy, political and legal authorities overlap, territorial exclusivity is replaced with functional boundaries, and states begin to speak with one voice. The article explores three interlinked aspects of late sovereign diplomacy: the teleological interpretation of the EC and EU treaties; the intense socialization of state representatives; and the negotiation process, which promotes national positions as part of a European cause, thereby delocalizing the national interest. While the EU has not rendered national diplomacy obsolete, it has profoundly changed its meaning and consequences.
\end{abstract}

\section{Keywords}

late sovereign diplomacy, European Union, national interest, doxa, socialization, legitimacy, constitutional pluralism

\section{Introduction}

A few decades ago, the institution of diplomacy in international society was perceived as being in decay and decline. The feelings of trust and shared responsibility for peace and orderly relations were disappearing. According to Hedley Bull, the cohesion of the global diplomatic system was disappearing:

\footnotetext{
*) An earlier version of this article was presented at the International Studies Association's Annual Convention, New York, in February 2009. I would like to thank the two editors of this special issue, Brian Hocking and Jozef Bátora, for their very constructive and insightful comments, which have substantially benefitted the argument. I am also grateful to the two anonymous reviewers for their valuable and helpful suggestions. I extend my special thanks to Chris Bickerton for his critical questions and inspirational ideas, and am also indebted to Rune Saugmann Andersen, Jens Bartelson, Benjamin de Carvalho, Ulrik Pram Gad, Martin Hall, Lene Hansen, Peter Viggo Jakobsen, Morten Kelstrup, Noel Parker, Anders Wivel, Trine Villumsen and Ole Wrever for their valuable comments.
} 
The solidarity of the diplomatic profession has declined since the mid-nineteenth century when
diplomatists of different countries were united by a common aristocratic culture, and often by ties
of blood and marriage, when the number of states were fewer and all the significant ones European,
and when diplomacy took place against the background of 'the international of monarchs' and the
intimate acquaintance of leading figures through the habit of congregating at spas.

This article argues that the diagnosis of an erosion of solidarity among diplomats was misguided - at least when it comes to the European Union. European integration has given rise to a re-emergence of feelings of solidarity among national representatives, which scholars described as lost 30 years ago. In the EU, the member states are united, if not by blood and marriage, then by what I call a late sovereign diplomacy' growing out of day-to-day negotiations in the Council of Ministers and its working groups. Late sovereign diplomacy is characterized by the intense legal, institutional and social integration of national representatives adhering to the sweeping notion of 'an ever closer union' and producing legislation that challenges the sovereignty of their own nations. A selected group of national representatives has come to share a collective identity that may be even stronger than that which could be found among aristocrats in the mid-nineteenth century. In this late sovereign order, the production of national and European interests is merging.

The first part of the article argues that EU scholars — be they from the liberal inter-governmentalist or multi-level governance camp - tend to understand the respective relationships among the member states along the lines of traditional diplomatic theory. From this perspective, it is difficult to explain the negotiation processes in the Council and their supranational traits. The article then proceeds to suggest that diplomacy within the EU should instead be understood from the perspective of what Neil Walker terms a 'late sovereign order'. Late sovereignty is a term used to describe the evolutionary process in Europe whereby legal and political authority has shifted away from the state to non-state polities particularly since the end of the Second World War. ${ }^{2}$

The third part of the article explores three interlinked aspects of late sovereign diplomacy in greater depth. Late sovereign diplomacy is characterized by a teleological interpretation of the EC and EU treaties, intense socialization between state representatives, and a negotiation process that promotes national interests as a contribution to the European project, thereby delocalizing the national interest. National representatives in Europe continue to perform many of the same tasks as they have done for centuries, such as writing aide-mémoires and organizing

\footnotetext{
1) Hedley Bull, The Anarchical Society: A Study of Order in World Politics (New York: Columbia University Press, 1977), p. 328.

2) Neil Walker, 'Late Sovereignty in the European Union', in Neil Walker (ed.), Sovereignty in Transition (Oxford and Portland OR: Hart Publishing, 2003).
} 
official state visits. ${ }^{3}$ Nonetheless, a late sovereign order leads to a qualitatively different form of state representation.

If traditional diplomacy is dialogue between states, diplomacy in the late sovereign phase can be regarded as a cacophony of different voices from states and non-state polities. In the late sovereign order, states are trying to speak with one voice and may even attempt to suppress their own voice. Will this eventually lead to the end of national diplomacy as we (think we) know it? The closing part of the article suggests that the ambiguous and contested nature of European integration has helped to transform diplomacy, but a genuine revolution or destruction of inter-state diplomacy in the EU is likely to remain a distant dream.

In the following, diplomats are understood to be officials who represent their member states in EU decision-making (whether formally employed in the diplomatic services or as members of the national civil services). The defining feature of diplomacy is thus the performance of official national representation. As will be clear, however, 'national representation' in a late sovereign order is different from what traditional diplomatic theory would want to be.

\section{Inside the Council of Ministers}

This section looks briefly at the understanding of the national representative in two major approaches to the EU - liberal inter-governmentalism and multilevel governance - and argues that the role of the diplomat is interpreted in a surprisingly conventional way. This calls for an alternative approach to diplomacy in the EU.

Following a liberal inter-governmentalist approach, regional integration is based upon situations in which the government aggregates the preferences of domestic groups into a consistent preference before carrying out international negotiations. ${ }^{4}$ At first glance, the liberal inter-governmentalist approach understands the EU in terms of a two-level game metaphor. ${ }^{5}$ According to this image, diplomacy always proceeds on two different levels at the same time: the international and domestic levels. Hence, during international negotiations, each national leader — or diplomat - must strike acceptable deals with his or her international partners and must ratify such deals in the respective domestic constituencies. The

\footnotetext{
3) See also Brian Hocking, 'Introduction: Gatekeepers and Boundary-Spanners: Thinking about Foreign Ministries in the European Union', in Brian Hocking and David Spence (eds), Foreign Ministries in the European Union: Integrating Diplomats (Basingstoke and New York: Palgrave, 2005), p. 9.

4) Andrew Moravcsik, 'Integrating International and Domestic Politics: A Theoretical Introduction', in Peter Evans, Harold Jacobson and Robert Putnam (eds), Double-Edged Diplomacy: Interactive Games in International Affairs (Berkeley CA: University of California Press, 1993).

5) Robert D. Putnam, 'Diplomacy and Domestic Politics: The Logic of Two-Level Games', International Organization, vol. 42, no. 3, 1988, pp. 427-460.
} 
statesman and his or her negotiators are constrained in their international negotiations by the interests of their constituents and what is acceptable to the other statesmen and negotiators. This reflects traditional understandings of inter-state bargaining. Thus, the liberal inter-governmental approach reproduces an image of member state relations in which the inside and outside of the state are clearly demarcated by diplomacy, or as Moravcsik puts it: 'The two-level games metaphor views the relationship between domestic and international politics through the eyes of the statesman'. ${ }^{6}$ In this view, diplomacy constitutes the state as a state - a separate entity that acts and has national interests that are distinct and separate from those of other states. Diplomats are seen as mediators between disparate - and not necessarily directly connected — worlds. $^{7}$

But how can this image of negotiation be upheld in the context of a European polity with supranational elements? Moravcsik adds a third level to his theory of liberal inter-governmentalism to understand the EU. The first two levels are similar to Putnam's two-level game, while the third employs elements that are drawn from regime theory. Supranational institutions tend to make cooperation more likely for many reasons, including the reduction of negotiation transaction costs. Once the procedure for negotiations in the EU has been decided, it becomes unnecessary to decide on them again. This renders all subsequent negotiations easier and less costly than the first negotiation.

Nonetheless, the liberal inter-governmentalist approach tends to assume a Westphalian and one-dimensional configuration of legal authority. Constitutional law is reserved for the internal order of the state, whereas international law governs relations between sovereign states. ${ }^{8}$ The fundamental principle guiding diplomacy is that the territorial sovereignty of states does not extend beyond their borders; each state exercises exclusive authority over its own territory. This means that the only claims to authority worth taking into account in the international order are those of the states. Indeed, this is why diplomacy can be defined as states speaking with each other. ${ }^{9}$

To many observers of the EU, however, liberal inter-governmentalism has not sufficiently helped us to understand the radical nature of European integration. Multi-level governance approaches are usually seen as the main challengers of state-centred interpretations of the EU and, one should think, also the traditional

\footnotetext{
6) Moravcsik, 'Integrating International and Domestic Politics', p. 23.

7) Iver B. Neumann, "'A Speech that the Entire Ministry may Stand For”, or: Why Diplomats Never Produce Anything New', International Political Sociology, vol. 1, no. 2, 2007, pp. 183-200.

8) Walker, 'Late Sovereignty in the European Union', p. 9.

9) Even if this has not always been a true and fair picture, it is the prevailing understanding of how diplomacy has functioned since the Peace of Wesphalia in 1648. From the perspective of international law, it can hardly be denied that 1648 marked an epoch in its evolution, not least by establishing the principles of political self-determination, non-intervention and legal equality between states. See Leo Gross, 'The Peace of Westphalia, 1648-1948', The American Journal of International Law, vol. 42, no. 1, 1948, pp. 20-41.
} 
vision of diplomacy. Theories of multi-level governance and Europeanization have successfully contested the previously dominant inter-governmental research agenda. ${ }^{10}$ In the multi-level governance approach, the state is but one of many actors in a multi-dimensional order with increasing specialization and socialization of national representatives. Accordingly, a national representative, who is bargaining on behalf of a state, need no longer be employed by a foreign office or foreign ministry, but may instead represent any national ministry or department that regularly engages in the Council system. The EU is not seen as an ordinary multilateral setting, but rather as a partly supranational setting in which actors such as the European Commission and the European Parliament are part of the negotiation process. ${ }^{11}$ Moreover, multi-level governance approaches assume that the sovereignty of the European state has been eroded and that informal policy networks have developed.

Nevertheless, multi-level governance scholars usually assume that national representatives defend particular national interests and speak solely for their states. ${ }^{12}$ The Council apparatus - consisting of the Council of Ministers, the Union presidency and the COREPER (Comité des Représentants Permanents) and its working groups - is seen as responsible for defending separate national preferences. The assumption is that the territorial principle predominates in the Council, while the functional or 'European' principle prevails in the supranational institutions. ${ }^{13}$ The functional principle entails that the supranational institutions, which are formally independent of the member states, are responsible for policy initiation and promoting the common European interest. Somewhat strikingly, while recognizing the complex character of decision-making in the EU - also in multi-level governance approaches - the Council is seen as representing national interests and traditional diplomatic bargaining. Although multi-level governance scholars have pinpointed the changes in the governance structure of the Union with its supranational elements, informal contacts between public and private actors and technocratization, they have generally refrained from exploring identity formation processes within the Council system. ${ }^{14}$

10) Gary Marks, Liesbet Hooghe and Kermit Blank, 'European Integration from the 1980s: State-Centric Versus Multi-Level Governance' Journal of Common Market Studies, vol. 34, no. 3, 1996, pp. 341-378. See also Tanja E. Aalberts, 'The Future of Sovereignty in Multi-Level Governance Europe: A Constructivist Reading', Journal of Common Market Studies, vol. 42, no. 1, 2004, pp. 23-46.

11) See Jozef Bátora, 'Does the European Union Transform the Institution of Diplomacy?', Journal of European Public Policy, vol. 12, no. 1, 2005, p. 56.

12) Morten Egeberg and Jarle Trondal, 'An Organization Theory Perspective on Multi-Level Governance in the EU: The Case of the EEA as a Form of Affiliation', ARENA Working Paper, no. 97/21 (Oslo: ARENA, 1997).

13) Brigid Laffan, 'The Social Psychology of Identity Change', in Richard K. Herrmann, Thomas Risse and Marilynn B. Brewer (eds), Transnational Identities: Becoming European in the EU (Lanham MD: Rowman \& Littlefield, 2004), p. 84.

14) See Simon Hix, 'The Study of the European Union II: The "New Governance" Agenda and Its Rival', 
To be sure, for governments and their administrations, the EU continues to represent a clearly different level of negotiations, which is demarcated from the domestic. British representatives still have to go to Brussels for Council working group meetings and they do not come empty-handed (or -headed), but bring instructions from London about specific goals and interests that they are expected to defend in these meetings. So while the supranational institutions are powerful, most scholars are inclined to assume that the member states' diplomatic practices remain fundamentally unchanged. Indeed, Council negotiations can be said to uphold the sovereign order in Europe. Yet if state interaction in the EU is only viewed from this perspective, a number of important qualitative changes will remain underexposed.

\section{The Late Sovereign Setting}

Today, any standard textbook on foreign policy analysis will emphasize that diplomacy has been transformed since 1945, and in particular since the end of the Cold War. But is diplomacy also qualitatively different in the EU compared to diplomacy in other multilateral venues such as the United Nations?

Without delving too deeply into the discussion of what the EU is, there are aspects that make it a unique setting. Ruggie has influentially argued that the conduct of politics among EU members resembles the medieval form of rule with its 'overlapping forms of authority' and 'non-exclusive forms of territoriality'. ${ }^{15} \mathrm{To}$ understand what this may imply, Neil Walker's notion of late sovereignty is helpful in capturing the immense legal and political transformations in Europe, particularly since the end of the Second World War. It should be stressed that the crude distinction between two different phases of sovereignty in Europe are idealtype characterizations rather than all-embracing categories. Accepting this, one can describe the Westphalian phase as characterized by territorially separated states in a one-dimensional configuration of political and legal authority, whereas the late sovereign order has rival representational practices of states and non-state polities with overlapping legal and political authority and competences. Late sovereignty displays considerable continuity with the old order, yet has distinctive features. Indeed, this combination of continuity and change is what renders 'late' sovereign diplomacy 'late' rather than 'post'.

Journal of European Public Policy, vol. 5, no. 1, 1998, pp. 38-65; and Marks, Hooghe and Blank, 'European Integration from the 1980s', pp. 270-271.

15) John Ruggie, 'Territoriality and Beyond: Problematizing Modernity in International Relations', International Organization, vol. 47, no. 1, 1993, pp. 139-174. The debate can be linked back to Bull, The Anarchical Society, pp. 254-255. For a detailed account of 'neo-medievalism' and its relevance for contemporary international relations, see Jörg Friedrich, 'The Meaning of New Medievalism', European Journal of International Relations, vol. 7, no. 4, 2001, pp. 475-501. 
In the age of late sovereignty, European states continue to claim territorial authority, but non-state polities also make claims to authority, often an authority that is bounded by function. Boundaries are no longer just territorial; they have also become functional. ${ }^{16}$ Hence, the EU effectively claims authority over policy sectors such as international trade, agricultural and monetary policy. It is no longer the minsters of trade from each member state, but the Trade Commissioner who represents and binds the member states collectively in the World Trade Organization (WTO). EU member states have no individual representation. The development of such functionally limited claims to competence does not mean that the territorial integrity of the state is threatened, but it opens up for a new conception of authority relations with numerous boundary disputes in a pluralist constitutional order.

As a consequence of these successful claims to authority, the EU itself has become a diplomatic actor with a full-blown external representation when it comes to trade and development aid, for instance, and a European Foreign Service is on its way. ${ }^{17}$ The Union increasingly acts diplomatically on the world scene in parallel with national diplomats. ${ }^{18} \mathrm{EU}$ member states have maintained their own embassies abroad, but EU citizens are also represented by the European Commission representations if they come to Ghana, Bolivia or China. What emerges is an image of diplomacy in which it is not just states speaking with states, but states speaking with non-state actors - or even non-state actors speaking on behalf of member states on the international scene.

As ultimate legal and political authority is exercised in a functional and not just a territorial logic, foreign ministries lose their monopoly to represent their nations in Brussels and other international organizations. Today, ministries of agriculture, trade, defence and finance send their own representatives to Council negotiations, often without much control and oversight from the foreign ministries. Accordingly, a diplomat need no longer be employed by a foreign office or foreign ministry, but may represent any national ministry or department with regular engagements in the Council system. In this sense, the EU is contributing to the disintegration of state authorities and the loss of power of foreign ministries. ${ }^{19}$

The following sections of this article discuss three interlinked aspects of late sovereign diplomacy that offer insights into exactly what may be changing and where old ideas and practices continue: the teleological interpretation of the

\footnotetext{
16) Walker, 'Late Sovereignty in the European Union', p. 23.

17) Michael Bruter, 'Diplomacy without a State: The External Delegations of the European Commission', Journal of European Public Policy, vol. 6, no. 2, 1999, pp. 183-205.

18) Simon W. Duke, 'Preparing for European Diplomacy?', Journal of Common Market Studies, vol. 40, no. 5 , 2002, pp. 849-870.

19) David Spence 'The Evolving Role of Foreign Ministries in the Conduct of European Union Affairs', in Brian Hocking and David Spence (eds), Foreign Ministries in the European Union: Integrating Diplomats (New York: Palgrave, 2005), p. 33.
} 
EC and EU treaties; the socialization of national representatives; and the delocalization of the national interest.

\section{Towards an Ever Closer Union}

A first feature of late diplomacy is the teleological interpretation of the EC and EU treaties that bind the member states and provide their negotiations with the purpose of overcoming their national differences. ${ }^{20}$ The fundamental aim of European integration is captured in the preamble of the Treaty of Rome, which states that the gathering nations of Europe are 'determined to lay the foundations of an ever closer union among the peoples of Europe'. Thus, when the states became EU members, 'they also implicitly signed up for more integration, because - in EC rhetoric - law (and obedience to law) has traditionally meant integration'. ${ }^{21}$

What makes the European Union unique compared to other international or regional forums for diplomacy is the solidness of its basic legal framework within the first pillar of the EC treaty, which consists of true public law and not merely recommendations or the expressions of intentions that are typical of international public law. No other international organization has hitherto proven as demanding as the EU when it comes to the political obligations and legal constraints that it places on its member states. The treaties establish a new form of relationship between the state and the EU polity, and member states are obliged to accept the European Court of Justice (ECJ) doctrine of the supremacy of EC law over national law, or in the words of the ECJ in the infamous Costa v. ENEL:

By creating a Community of unlimited duration, having [...] powers stemming from a limitation of sovereignty, or a transfer of powers from the States to the Community, the Member States have limited their sovereign rights, albeit within limited fields, and thus have created a body of law which binds both their nationals and themselves. ${ }^{22}$

The treaties and ECJ case law glue the EU member states together in an unprecedented fashion: all EU member states' national legal systems must deal with the ECJ's claim to supremacy over national law. Nevertheless, as Karen Alter has stated, 'The ECJ can say whatever it wants, the real question is why anyone should heed it'. ${ }^{23}$ True enough, the ECJ may make it increasingly difficult for EU member states to act as they please, but this does not mean that they stop being sovereign or no longer defend their national interests. However, law is not only

\footnotetext{
20) Jo Shaw, 'European Union Legal Studies in Crisis? Towards a New Dynamic', Oxford Journal of Legal Studies, vol. 16, no. 2, 1996, p. 231-255.

21) Shaw, 'European Union Legal Studies in Crisis?', p. 237.

22) Case 6/64, [1964] ECR 585, 593.

23) Karen J. Alter, 'The European Court's Political Power', West European Politics, vol. 19, no. 3, 1996, p. 458.
} 
regulative of behaviour; it may also play a constitutive role in the formation of actors' identities and interests and in the structure of the international system itself. ${ }^{24}$ This insight is often ignored in studies of diplomatic interaction in the EU.

The idea of 'an ever closer union' serves to legitimize the EU's actions to its own civil servants, including the national representatives based in Brussels. It is part of their self-perception about what they are doing and constitutes part of their own identity. Of course, such ideas are only transformed into political ideology when they are able to mobilize society or social forces. Until then, they merely remain a set of ideas shared by a sociologically limited group of people - in this case, a few thousand bureaucrats and national representatives who meet in Brussels.

Even if this self-legitimation has not become a genuine ideology, it does contribute to making diplomacy in Brussels a radical phenomenon. In their negotiations, EU member state representatives work in a particular direction, more or less consciously sharing the common goal of fulfilling the aims of the treaties. They work within what Bourdieu would call a doxa, which 'operates as if it were the objective truth across social space in its entirety'. ${ }^{25}$ This doxa of European integration covers the tacit assumptions that are fundamental to the European project. Doxa is the undiscussed premise that makes negotiations in the EU meaningful in the first place and upon which agents act. Indeed, the idea that Europe must continue to move forwards is a shared assumption that is very rarely questioned by any national representative. They may not always agree on where the EU should be moving or how fast, but it should move forwards.

One of the most important ways in which the EU moves forwards is through law. In the Council, diplomats translate the abstract notions of 'an ever closer union' into negotiations on secondary legislation in the form of regulations and directives. In other words, national representatives produce more than just decisions; they create new legislation in cooperation with the supranational institutions, legislation that may have direct and immediate effect in their member states.

\section{When in Brussels...}

Linked to the doxa of 'an ever closer union' is deep socialization, which is a second feature of late sovereignty. Social interaction between nation-state representatives is much more intensive in the EU than anywhere else in the world, which increases the possibility of transfer of loyalties. ${ }^{26}$ From this perspective, the neo-functionalist

\footnotetext{
24) Jo Shaw and Antje Wiener, 'The Paradox of the European Polity', in Maria Green Cowles and Mike Smith (eds), State of the European Union 5: Risks, Reform, Resistance and Revival, (Oxford: Oxford University Press, 2000).

25) Pierre Bourdieu, In Other Words (Stanford CA: Stanford University Press, 1990).

26) Socialization can be understood as a process of inducting agents into the norms and rules of a given
} 
legacy might seem relevant to the study of diplomacy in the EU. Neo-functionalists such as Lindberg stressed that elite socialization was a key to understanding European integration; in the Council, problem-solving is dominant and 'the normal practice is to exclude the possibility of not reaching an agreement at all'. ${ }^{27}$ However, neo-functionalism failed to link the negotiation processes in the Council with the teleological interpretation of the treaties and the doxa of 'an ever closer union', thereby ignoring a crucial aspect of state interaction in Europe.

The EU is a formal international organization, established by states through international legal rules, but these legal rules in turn affect the identities of the representatives of its member states. In short, the politico-administrative elites in the EU member states have been undergoing a 'Europeanization of national identity..$^{28}$ Over the years, since the foundation of formal European institutions, 'leading political forces [...] have increasingly come to view their nations as anchored within European institutions and to recognize the EU as a legitimate framework for politics'. ${ }^{29}$

This merging of the national and European interests in the EU goes uncontested in most cases. It has helped the member states work together peacefully on very advanced projects of regional cooperation that demand a high degree of mutual trust. Without intense contacts, there would be no integration in sensitive issues such as monetary policy, common defence and criminal law. ${ }^{30}$ Identification with the European project can increase in tandem with continued identification with the nation-state. If this dual-identity structure works well, national and European identification can be mutually reinforcing. ${ }^{31}$

The fact that national representatives assume the role of bureaucrats participating in the construction of a non-state polity does not entail that they agree on the type of polity. There are divergences over, for example, which kind of asylum policy should be followed, how much sovereignty the state is willing to give up or how the member states' economic policy should be coordinated. The dual purpose of diplomacy is therefore not indicative, necessarily, of any form of unification of positions. Being prepared to accept the principles of supranationality and

community; see Jeffrey T. Checkel, 'International Institutions and Socialization in Europe: Introduction and Framework', International Organization, vol. 59, no. 4, 2005, pp. 801-826.

27) Leon N. Lindberg, 'The Political Dynamics of European Economic Integration', in Mette EilstrupSangiovanni, Debates on European Integration: A Reader (Oxford: Oxford University Press, 2006), p. 127. See also Ben Rosamond, 'The Uniting of Europe and the Foundation of EU Studies: Revisiting the NeoFunctionalism of Ernst B. Haas', Journal of European Public Policy, vol. 12, no. 2, 2005, pp. 237-254.

28) Thomas Banchoff, The German Problem Transformed: Institutions, Politics, and Foreign Policy, 19451995, (Ann Arbor MI: University of Michigan Press, 1999).

29) Banchoff, The German Problem Transformed, p. 22.

30) Jeannette Mak, 'Informality as an Asset? The Case of EMU', in Thomas Christiansen and Simona Piattoni (eds), Informal Governance in the European Union (Cheltenham: Edward Elgar, 2003), p. 205.

31) Richard K. Herrmann and Marilynn B. Brewer, 'Identity and Institutions: Becoming European in the EU', in Richard K. Herrmann and Marilynn B. Brewer (eds), Transnational Identities: Becoming European in the EU (New York: Rowman \& Littlefield, 2004), p. 12. 
economic integration and to work effectively together is not the same as losing sight of national interests. While national officials assume that legitimate authority stems from non-elected supranational bodies such as the Commission as well as state-based elected and non-elected representatives, this does not mean that their loyalty to the common endeavour is a zero-sum game. Rather, it reflects a more pragmatic and experienced idea that one is influential if one can come up with common solutions. ${ }^{32}$

Importantly, socialization not only occurs among officials in supranational bodies such as the European Commission but in the Council system as well, where national representatives adopt norms and rules of appropriateness. ${ }^{33} \mathrm{Nego-}$ tiations in the inter-governmental Council are far more institutionalized (both formally and informally) than, for instance, negotiations in the United Nations. ${ }^{34}$ All of the member states have a permanent EU representation in Brussels to represent their interests, and ministers and diplomats know each other much more than they did when the integration process began in the 1950s and 1960s.

Negotiations in Brussels produce a cohort of officials in each member state, notably those who have worked in the permanent representations and the Council working parties. They are spread throughout the national administrations in the ministries of finance, agriculture, foreign policy, defence, justice and home affairs, etc. This small elite of officials promotes national preferences but is also committed to the collective outcomes. They see themselves as working both for Europe and for their country and usually do not see any contradiction between the two, thus merging functional and territorial principles in their daily work. As Brian Hocking notes, the diplomat in Europe is no longer a gatekeeper between the inside and outside of the state; rather, he or she is a boundary-spanner in a complex, transnational space. ${ }^{35}$

Along these lines, it has been argued that the European diplomatic service constitutes 'an epistemic community of experts who often exercise their own agency separate from member state preferences'. ${ }^{36}$ This analysis implies, however, that member state preferences are generated domestically and subsequently represented in Brussels. The argument rests on an assumption of the decoupling of national preference formation and subsequent negotiations in the Council. The 'real' national preferences are not 'respected', so as to speak. However, this interpretation essentially builds upon a distinction between what is national and what

32) Jeffrey Lewis, 'The Janus Face of Brussels: Socialization and Everyday Decision-Making in the European Union', International Organization, vol. 59, no. 4, 2005, pp. 937-971.

33) Laffan, 'The Social Psychology of Identity Change', pp. 87-88. See also Lewis, 'The Janus Face of Brussels'; and Checkel, 'International Institutions and Socialization in Europe'.

34) Bátora, 'Does the European Union Transform the Institution of Diplomacy?', p. 56.

35) Hocking, 'Introduction'.

36) Mai'a Keapuolani Davis Cross, 'A European Epistemic Community of Diplomats', in Paul Sharp and Geoffrey Wiseman, The Diplomatic Corps as an Institution of International Society (New York: Palgrave, 2007), pp. 224-225. 
is European and thus fails to grasp fully the character of late sovereign diplomacy. Its most significant feature is not the gap between the national and international scenes (this is hardly a new phenomenon in diplomatic practice, after all); rather, the crucial difference compared to two-level game diplomacy is that the very construction of a national position takes place as part of a struggle for distinction and dominance in a field where the stakes have already been defined.

\section{Delocalization of the National Interest}

A third feature of late sovereignty in the EU is the delocalization of national interest. National interest is defined in Brussels just as much as it is in Berlin, Ljubljana or Madrid. The diplomats' understanding of the objective of their negotiations is pieced together not only by their ministries and parliament back home, but just as much by their European colleagues. The physical displacement of diplomats in the Permanent Representations reflects an ideational shift, in the sense that the national interest is produced in a transnational field among officials sharing a Europeanized habitus or sens pratique. ${ }^{37}$ Diplomacy in the EU cannot simply be described as mediation between the domestic and European levels.

To examine how the construction of national interest has been detached from domestic institutions, it is useful to examine how national negotiation positions are established in practice. In order to be able to play its role as 'guardian of the treaties' and 'defender of the general interest', the Commission has been given the right of initiative, which empowers and requires it to make proposals on the matters contained in the treaty, either because the treaty expressly so provides or because the Commission considers it necessary. This power of initiative is exclusive in respect of Community matters, the principle being that the Council makes decisions only 'on a proposal from the Commission', so that there is a coherent framework for all initiatives. In the case of the second (common foreign and security policy) and third (police and judicial cooperation in criminal matters) pillars, this right of initiative is shared by the Commission and the member states, and unanimity in the Council is generally necessary, although almost all legislation will be adopted though the community method with the Lisbon Treaty.

Because the initiative generally rests with the Commission, a national position must be expressed in the form of a contribution - positive or negative - to the Commission's proposals. This is essentially a reactive performance. It is well known that the Commission is in close contact with the capitals before it proposes new legislation to ensure that it goes down well, but it is the member states closest to the Commission's pro-integrationist position that emerge as 'winners' in

37) Rebecca Adler-Nissen, 'The Diplomacy of Opting Out: A Bourdieudian Approach to National Integration Strategies', Journal of Common Market Studies, vol. 46, no, 3, 2008, pp. 663-684. 
the negotiations..$^{38}$ National diplomats can play a proactive role by lobbying the Commission, European Parliament and the other member states before proposals for new legislation or decisions are formally put on the negotiation table. For more EU-sceptical countries, this situation requires much work. As former UK ambassador to the EU Stephen Wall writes:

The amount of effort which the UK Representation in Brussels puts into keeping alongside the Commission and the EP [European Parliament] certainly exceeds that of most other member governments. ${ }^{39}$

The general picture of EU decision-making is thus that the Commission proposes new legislation, which the Council then takes over and modifies, together with the European Parliament, before it becomes binding. ${ }^{40}$

In this process, where the national interest is delocalized, national representatives assume the role of technocrats participating in the construction of a nonstate polity. This becomes evident if one considers the level of specification in new EU legislation, which has reached a point comparable to national law. Legal instruments such as the Directive 2001/43/EC relating to 'tyres for motor vehicles and their trailers and to their fitting' and Directive 2004/24/EC on 'traditional herbal medicinal products' are negotiated in the Council system, but they have very little to do with defeat or victory for the nation; rather, to paraphrase European Commission President José Manuel Barroso, they relate more to the creation of a 'Europe of results'. In the late sovereign order with overlapping competences, the ultimate purpose of diplomacy is not merely to mediate between states and promote national interests in a peaceful manner, but also to solve common problems in a legally and politically constraining polity.

However, there is a catch to this argument. One could argue that being dualpurposed is a general feature of all diplomacy, in the sense that diplomacy functions as a means of conserving a particular, often peaceful, order. ${ }^{41}$ While the polity-building agenda may thus sound radical, it is in fact merely a reflexion of

38) Stephanie Bailer, 'Bargaining Success in the European Union: The Impact of Exogenous and Endogenous Power Resources', European Union Politics vol. 5, no, 1, 2004, pp. 99-123.

39) Stephen Wall, $A$ Stranger in Europe: Britain and the EU from Thatcher to Blair (Oxford: Oxford University Press, 2008), p. 202.

40) After preparation in COREPER, proposals enter Council deliberations labelled either as 'A-points' or 'B-points'. A-points are decisions that have already been made by COREPER and are therefore accepted without discussion in the Council. B-points are proposals on which the COREPER could not agree and thus need to be discussed and possibly voted upon by the ministers. Empirical studies show that up to 90 per cent of Council decisions are A-points. See Jeffrey Lewis 'Institutional Environments and Everyday EU Decision-Making: Rationalist or Constructivist?', Comparative Political Studies, vol. 36, no. 1, February 2003, pp. 97-124.

41) According to Mayall, the underlying rationale of the diplomatic profession is to facilitate orderly and peaceful relations among states; see James Mayall, 'Introduction', in Paul Sharp and George Wiseman (eds), The Diplomatic Corps as an Institution of International Society (Basingstoke: Palgrave Macmillan, 2007), p. 6. 
what Neumann refers to as the general trick to being a diplomat, namely '[...] to concentrate on the here and now, on keeping the wheels turning..$^{42}$ Keeping the wheels turning in the EU, however, goes beyond safeguarding an existing order; it necessarily also involves participating in the construction of new policies.

In sum, diplomacy in the EU remains centred on representing the interests of the member states against other member states in the Council of Ministers, which is where we observe continuation. However, the actual formulation of the national interest proceeds within a diplomatic space in Brussels, which is focused on constructing a European polity that limits the sovereignty of its member states. Member state representatives may continue to think in terms of national interest, but they do so in ways that are different from 50 years ago.

\section{Speaking With One Voice}

Nevertheless, there is definitely a new trend in the EU that appears to point in the opposite direction, namely the shift away from supranationalism towards decision-making that is dominated by the European Council - that is, the heads of state and government. The growing number of bilateral meetings and summits between EU member states' political leaders could be viewed as a return to classical diplomacy between sovereigns. ${ }^{43}$ When the heads of state reach agreement among themselves, they are often far removed from the supranationalism of the community method. I would argue, however, that this is not a return to the good old days of sovereign diplomacy, but part of the trend where 'Europe speaks with one voice'.

The recent financial crisis offers a case in point. At the extraordinary summit on 12 October 2008 between the heads of state from the euro area and the United Kingdom, the result initially appears to be the prevalence of national solutions. French President Sarkozy's original idea of a common European bank bailout fund was dropped in the face of German resistance to being seen as paying for others. The current rescue plans may have been coordinated, but the details are being decided by individual national governments, and no money is being pooled. In other words, Sarkozy's satisfaction with the summit at the subsequent press conference was a mere cover for different national policies with beggar-thy-neighbour consequences to which a pan-European agreement was tacked.

Nonetheless, it is premature to interpret this as a 'renationalization' of European integration because it would be erroneous to see the increasing number of high-level summits as merely aiming at producing concrete decisions. The summits are part of a larger transformation of how 'good statesmanship' is perceived

42) Iver B. Neumann, 'To Be a Diplomat', International Studies Perspectives, vol. 6, no. 1, 2005, pp. 72-93.

43) See Josef Janning, 'Leadership Coalitions and Change: The Role of States in the European Union', International Affairs, vol. 81, vol. 4, pp. 821-831. 
in contemporary Europe. At the press conference, Sarkozy expressed satisfaction with the negotiations, underlining that they reflected a concerted approach and that he wanted 'Europe to speak with one voice'. In fact, Sarkozy was standing next to Commission President Barroso, who also issued assurances to journalists regarding European unity. The many attempts to 'speak with one voice' should be analysed as an effort to disseminate normative and cognitive frameworks, not just as covering hard bargains. The very idea that 'we are doing something together' was an important message at the press conference. Hence, the myth of a unified Europe is reproduced at EU summits as the depoliticized results of consensus among member states.

From this perspective, Sarkozy's 'Euro-speak' assumes a language that 'works to connect those inside the institutions [...] and, simultaneously, to exclude and set apart those who are outside it'. ${ }^{44}$ Strengthening the European Council can be seen as a governmental technique, which — just as the foreign and security policy — is driven and legitimized as much by attempts to overcome national differences and unite as it is about actually playing a role in the world ${ }^{45}$ Diplomatic success today is largely measured in terms of the ability to find a common position and to make Europe speak with one voice. How that voice should sound is less important.

\section{Tempering Transformation}

Will the EU's claims to supreme legal authority and limits on national sovereignty mean a goodbye to diplomacy as we know it? At a time when the newly appointed British defence secretary, John Hutton, has accepted the establishment of a permanent EU army, it seems fair to raise some fundamental questions: If the legalization and socialization processes continue in Europe, what remains of independent national diplomacy? If the EU speaks with one voice, what happens to the national voices? When attempting to imagine what may follow late sovereignty, one must ask the fundamental question of how a global order can be conceived without representatives of separate political polities. ${ }^{46}$ Not only has the context in which diplomacy takes place changed, but the very meaning of diplomacy also seems to be shifting in Brussels. Together with the supranational institutions, national representatives are participating in the creation of a common European language that shapes their understanding of the negotiations.

\footnotetext{
44) Annica Kronsell, 'Gender, Power and European Integration Theory', Journal of European Public Policy, vol. 12, no. 6, 2005, p. 1034.

45) See also Christopher J. Bickerton, 'The Perils of Performance: Legitimization in EU Foreign Policy', Perspectives: The Central European Review of International Affairs, vol. 28, 2007, p. 37.

46) See also Walker, 'The Variety of Sovereignty', in Rebecca Adler-Nissen and Thomas GammeltoftHansen (eds.), Sovereignty Games: Instrumentalizing State Sovereignty in Europe and Beyond (Basingstoke: Palgrave, 2008), pp. 21-32 at p. 31.
} 
It is important, however, to moderate the claims of a transformative nature of intra-EU diplomacy. One should refrain from assuming that these trends represent the terminal phase of diplomacy in Europe, because late sovereign diplomacy also has inbuilt conservative features. There are at least two reasons for tempering the idea that late sovereign diplomacy will transform diplomacy fundamentally. First, the doxa of integration is intrinsically ambiguous. The fundamental idea behind the EU is that it should never reach the crucial point where the state is no longer different from another state; when it can no longer make sovereignty claims to supreme and ultimate authority over its territory. Should that happen, the diplomatic task of moving Europe forwards would no longer be meaningful. Of course, national representatives must accept that other states and entities make competing and sometimes more successful claims to sovereignty - this is a critical element in late sovereign diplomacy. However, there must be no clear endpoint of integration. ${ }^{47}$ This is the paradox of European integration. The notion of an 'ever closer union among the peoples of Europe' requires that one can still speak of separate 'peoples' and hence that the EU should remain a polity with separate and sovereign states. ${ }^{48}$ An increasing number of areas may become supranational and integration may become so overwhelming that the state has essentially lost all autonomy, but as long as state representatives can continue to make effective calls for sovereignty and the finalité debate remains abstract, late sovereign diplomacy will have a long shelf-life.

Should national representatives forget about this self-limitation clause that is built into the constitutional structure of the EU, others will remind them that their transcendental project is fragile, because it is only fully shared by a small European elite. In light of the French and Dutch rejections of the Constitutional Treaty in 2005 and the subsequent negative Irish vote on the Lisbon Treaty in 2008, objections to the EU orthodoxy are likely to become more prominent in the coming years. The doxa of 'an ever closer union' will be challenged by calls for increased differentiation in the form of national opt-outs and exemptions. The Polish declaration to the Charter on Fundamental Rights in the Lisbon Treaty represents an EU-sceptic view, which was previously only rarely framed among the political and diplomatic elite. New generations of heads of state and government and their national representatives will enter the European scene with a different understanding of the purpose of European diplomacy, thereby strengthening sovereign diplomacy vis-à-vis the orthodox integration mode. Future enlargement rounds may also question the existing doxa, although it has been demonstrated that

\footnotetext{
47) Dario Castiglione, 'Reflections on Europe's Constitutional Future', Constellations, vol. 11, no. 3, 2004, pp. 393-411; Marlene Wind, 'The European Union as a Polycentric Polity: Returning to a NeoMedieval Europe?', in J.H.H. Weiler and Marlene Wind (eds), Constitutionalism beyond the State (Cambridge: Cambridge University Press, 2003).

48) J.H.H. Joseph, 'In Defence of the Status Quo: Europe's Constitutional Sonderweg', in Weiler and Wind (eds), Constitutionalism beyond the State, p. 10.
} 
the national representatives from the new member states adapt quickly to the informal norms of the Council system. ${ }^{49}$

\title{
Controlling Late Sovereign Diplomacy
}

Negotiations in the EU are centred on representing the interests of the member states against other member states, but the actual handling of the national interest - understood as a negotiating position - takes place within a transnational diplomatic field in Brussels that is focused on constructing a European polity. National interest does not disappear in the EU, but it is far less socially mediated than most accounts of the EU and Council negotiations are inclined to believe.

A critique of this development would begin by arguing that this brings us back to earlier forms of realpolitik, where actions were more those of individual leaders and their advisers than those of nations or people. Interests, yes - but not 'national' as such. In this view, national positions in the EU do not always have the strength and absoluteness of interests with the weight of society behind them. Stated more radically:

\begin{abstract}
We see that sovereignty, as the forceful assertion of national interests and ambitions, is less appropriate to the actual behaviour of today's elites. On the contrary, European integration begins to look somewhat like Althusser's 'process without a subject'. Sovereignty survives as performance, but its content is attenuated..$^{50}$
\end{abstract}

Heartfield's argument points out the naivety of the two-level game assumption, which supposes a much stronger and more direct link between national preference formation (whatever that may be taken to mean) and Council negotiations. However, the problem with Heartfield's argument is that it assumes that sovereignty was once a 'forceful assertion of national interests and ambitions'. In pointing out the links between late sovereignty order and a small diplomatic elite in the EU engine room, one should avoid falling into the opposite trap of essentializing the national interest as having a particular 'vitality'. National representatives who develop policy within Brussels share many assumptions and inhabit the same world, but so did the aristocratic diplomats of 1850 . Rather, the polity-building agenda of European integration suggests that EU diplomacy goes beyond an

\footnotetext{
49) Jacob Lempp and Janko Altenschmidt, 'The Prevention of Deadlock through Informal Processes of "Supranationalization": The Case of COREPER', Journal of European Integration, vol. 30, no. 4, 2008, pp. 511-526.

50) James Heartfield, 'European Union: A Process Without a Subject', in Christopher J. Bickerton, Philip Cunliffe and Alexander Gourevitch (eds), Politics Without Sovereignty: A Critique of Contemporary International Relations (London: Routledge, 2007), p. 147.
} 
intense integration of the diplomatic elite's worldviews; it points out problems of accountability.

Some years ago, Allot predicted that democracy would replace intra-European diplomacy. ${ }^{51}$ This 'replacement' has yet to be seen. When national interests are Europeanized, it is once again germane to raise the fundamental questions of why we have diplomacy and for whom diplomacy works. ${ }^{52}$ In this respect, there are at least two reflections that merit consideration. One approach is to call for a return to 'sovereign diplomacy'; another is to assume the transition to late sovereignty and to 'go democratic'. Sharp advocates the former. To avoid becoming a source of international tension:

[D]iplomats should remind themselves and others that they are first and foremost the representatives of sovereign states, that this is their raison d'être and a precondition for anything else they may aspire to be or do. ${ }^{53}$

In the current multi-dimensional European order, however, the raison d'être of national diplomacy has changed, perhaps for good. Indeed, European integration would not have been possible had this not been the case. Thus, while Sharp's comment is a valuable reminder, it will not be able to match the EU's overlapping authority structures and the supranational decision-making process.

An alternative route to thinking about how to make diplomacy in the EU more accountable assumes that we have entered a late sovereign order for good. According to this view, the challenge is not to roll back integration, but to introduce new checks and processes that will supposedly increase its accountability. ${ }^{54}$ We are likely to see greater parliamentary control, both on the national and European scenes. Stronger involvement by national parliaments in the decisionmaking process will possibly link national representative practices more directly to the debates in national capitals and give rise to demands that the bargains in Brussels reflect particular national problems. Nonetheless, it is doubtful whether initiatives such as giving national parliaments the power to block new legislation through the use of 'red cards' will change how late sovereign diplomacy functions. Rather, they may have the opposite effect in terms of increased frustration, both for diplomats and the populations that they represent. ${ }^{55}$

\footnotetext{
51) Allot, quoted in Knud Erik Jørgensen, 'Modern European Diplomacy: A Research Agenda', Journal of International Relations and Development, vol. 2, no. 1, 1999, p. 86.

52) Late sovereign diplomacy is linked to the reflexion or self-confrontation, which is characteristic of late modernity; see Ulrich Beck, The Reinvention of Politics: Towards a Theory of Reflexive Modernization (Cambridge: Polity Press, 1994).

53) Paul Sharp, 'Who Needs Diplomats? The Problem of Diplomatic Representation', in Christer Jönsson and Richard Langhorne (eds), Problems and Issues in Contemporary Diplomacy, Volume III (London: Sage, 2004), p. 76.

54) See Andreas Follesdal and Simon Hix, 'Why There Is a Democratic Deficit in the EU: A Response to Majone and Moravcsik', Journal of Common Market Studies, vol. 44, no. 3, 2006, pp. 533-562.

55) See also Gráinne de Búrca, 'The Quest for Legitimacy in the European Union', The Modern Law Review, vol. 59, no. 3, 1996, pp. 349-376.
} 
Based on the above, I would argue that any new institutional mechanism created to install external controls will be interpreted and reinterpreted by diplomats assuming that legitimate authority not only stems from state-based elected and non-elected representatives, but also from non-elected supranational bodies. Whether or not reproducing national systems of 'accountability' and 'representation' - in a system in which national representation serves both national and European agendas - will have the desired effect ought to be explored further in empirical analyses. But creating fundamental changes in the way that states negotiate in the European Union would require radical reforms, not only to the institutional set-up, but also to the diplomatic identities, social hierarchies and the sense of purpose of the integration process.

\section{Beyond the European Union?}

One could speculate that the EU's polity-building agenda is a more general feature of contemporary diplomacy. As Paul Sharp notes in a critique of post-Cold War diplomacy:

Representation — of sovereigns, interests, or ideas — was replaced by metaphors of constructing and building by which issues were to be managed and problems were to be solved. ${ }^{56}$

According to Sharp, the modern diplomat moves away from representing the notion of a sovereign state towards engineering new international institutions. Yet, one should carefully specify the area of validity. It seems obvious that a systems-wide phenomenon such as diplomacy may not be directly affected by what goes on between one of the system's units - that is, the EU. This is not to say that diplomacy is not changing on a global level, but this debate must be studied at the level of the global system, for example as a result of globalization processes. ${ }^{57}$

One might instead ask whether there are other international organizations with dynamics that are similar to those identified above. Outside Europe, it is more difficult to identify the same degree of integration between national representatives that we find in the European Union. Trade organizations such as the WTO and regional organizations such as the Association of South-East Asian Nations (ASEAN) and Mercosur (from the Spanish Mercado Común del Sur) could be possible and interesting comparisons. Contrary to the EU, however, these organizations are inter-governmental in nature. ${ }^{58}$

56) Sharp, 'Who Needs Diplomats?', p. 67.

57) See Andrew F. Cooper, Brian Hocking and William Maley (eds), Global Governance and Diplomacy: Worlds Apart? (Basingstoke: Palgrave Macmillan, 2006).

58) Amitav Acharya, Constructing a Security Community in South-East Asia: ASEAN and the Problem of Regional Order (London: Routledge, 2001); and Andre Malamud, 'Mercosur Turns 15: Between Rising Rhetoric and Declining Achievement', Cambridge Review of International Affairs, vol. 18, no. 3, 2005, pp. 421-436. 
Although the WTO lacks fundamental elements of supranational law - such as superiority and direct effect - it is 'functionally equivalent to supranational law' and has become a further layer of governance. ${ }^{59}$ However, the WTO is short of some of the features that render European diplomacy late sovereign: the WTO reaches decisions by consensus among some 150 member states; there are no supranational institutions participating in the negotiations; and more crucially, the WTO does not have a polity-building agenda. Indeed, the key to understanding diplomacy in the European Union is the unprecedented nature of the EU itself and the novel role that national officials play in representing member states while making decisions in the name of a supranational authority.

\section{Conclusion}

This article has argued that national representatives have contributed to a silent transformation of diplomacy in Europe during the last 50 years. Neither the twolevel game metaphor of liberal inter-governmentalism nor the territorial logic of multi-level governance offer adequate accounts of the diplomatic practices within the EU. In many instances, the national interest is no longer framed as the state's interests for itself, but as the state's ambitions for the EU. When defending positions in the Council, national representatives participate actively in the construction of a late sovereign order. Within the EU diplomatic interaction does not merely involve sovereign states speaking with each other; rather, political and legal authorities overlap, territorial exclusivity is replaced with functional divisions of powers, and states begin to speak with one voice.

There are at least three distinct - although interrelated - features of late sovereign diplomacy in the European Union: the purpose of diplomacy is not merely mediation between states, but the creation of 'an ever closer union'; national representatives are undergoing intense socialization; and the national interest is delocalized. While socialization may be seen as a return to the 'good old days' of intimate European aristocracy, teleological and delocalized diplomatic practices could be a novelty because the diplomat is not only a mediator but also a constructor of a non-state polity that rivals the state. Beyond Europe, however, it is more difficult to identify the same dynamics that characterize the late sovereignty phase of diplomacy.

Moreover, conventional and transcendental dynamics are not mutually exclusive. The coexistence of ideas of traditional national interests and a common European interest is at the core of diplomatic practices in the late sovereign phase. Sovereign statehood survives in the minds and practices of those that represent

59) Markus Krajewski, 'Democratic Legitimacy and Constitutional Perspectives of WTO Law', Journal of World Trade, vol. 35, no. 1. 2001, p. 171. 
the state in Europe. ${ }^{60}$ This simultaneousness is also what creates the many tensions in late sovereign diplomacy. Because the doxa of 'an ever closer Union' is fundamentally ambivalent, the late sovereign phase will likely be lengthy.

The late sovereign phase of diplomacy raises fundamental questions about accountability in a multi-dimensional order with its constitutional pluralism and an uneasy combination of 'national' and 'common' interest. Any genuine and lasting EU reform must consider that national diplomacy in the EU is no longer what it used to be.

Rebecca Adler-Nissen is a Research Fellow in the Department of Political Science at the University of Copenhagen in Denmark. Her research focuses on diplomacy, differentiated integration and the transformation of statehood in the European Union. Her Ph.D. thesis explores British and Danish EU opt-outs and their consequences for national diplomacy and the European polity. She is currently also working on international political sociology and the relationship between law and politics. She is co-editor (with Thomas Gammeltoft-Hansen) of Sovereignty Games: Instrumentalizing State Sovereignty in Europe and Beyond (Basingstoke: Palgrave, 2008). Other recent publications include 'The Diplomacy of Opting Out: A Bourdieudian Approach to National Integration Strategies', Journal of Common Market Studies, 2008; and 'Behind the Scenes of Differentiated Integration', Journal of European Public Policy, 2009. She was awarded the Gold Medal of the University of Copenhagen for her co-authored treatise (in Danish) on democratic theory, hermeneutics and the EU's Constitutional Treaty (Copenhagen: Djøf, 2005).

60) Aalberts, 'The Future of Sovereignty in Multi-level Governance Europe'. 